\title{
The effect of temperature on the diapause and cold hardiness of Dendrolimus tabulaeformis (Lepidoptera: Lasiocampidae)
}

\author{
Ju-PING ZENG ${ }^{1,2}$, FenG GE $^{1 *}$, JiAn-WeI SU ${ }^{1}$ and Yong WANG ${ }^{3}$ \\ ${ }^{1}$ State Key Laboratory of Integrated Management of Pest Insects and Rodents, Institute of Zoology, \\ Chinese Academy of Sciences, Beijing 100101, P.R. China \\ ${ }^{2}$ Graduate University, Chinese Academy of Sciences, Beijing 100049, P.R. China \\ ${ }^{3}$ Hunan Agricultural University, Changsha 410128, P.R. China
}

\begin{abstract}
Key words. Dendrolimus tabulaeformis, acclimation, de-acclimation, cold hardiness, supercooling point, low molecular weight
\end{abstract} sugars

\begin{abstract}
Pine caterpillar, Dendrolimus tabulaeformis Tsai et Liu, is a major pine pest in North China. The larvae enter diapause in the third or fourth instar before winter. Supercooling points (SCP) and cold hardiness of the diapausing larvae were investigated and compared in non-acclimated, acclimated and de-acclimated larvae. A bimodal frequency distribution was observed with a break point of $-14^{\circ} \mathrm{C}$ in the SCP. Larvae in the low group ( $\mathrm{LG}, \mathrm{SCP} \leq-14^{\circ} \mathrm{C}$ ) were more cold tolerant with lower lethal temperatures than those in the high group $\left(\mathrm{HG}, \mathrm{SCP}>-14^{\circ} \mathrm{C}\right)$. This bimodality occurred in three patterns, $\mathrm{LG}(>60 \%$ of individuals in $\mathrm{LG})$, $\mathrm{LG}-\mathrm{HG}$ $(<60 \%$ of individuals in LG and $\mathrm{HG})$ and $\mathrm{HG}(>60 \%$ of individuals in $\mathrm{HG})$, in response to cold acclimation and de-acclimation. The cold hardiness was ranked as: $\mathrm{LG}>\mathrm{LG}-\mathrm{HG}>\mathrm{HG}$ pattern. Cold hardiness was enhanced by an increase in concentrations of trehalose, galactose, glucose and mannose in the haemolymph as well as by decrease in metabolism after cold acclimation, but was lost after de-acclimation. Loss of cold hardiness was correlated with decrease in sugars and increase in metabolic rate. In conclusion, the species is a chill tolerant insect, adopting the strategy of depressing SCP through accumulation of low molecular weight sugars in the haemolymph, concomitant with metabolic depression.
\end{abstract}

\section{INTRODUCTION}

Few temperate insects are able to avoid exposure to low environmental temperatures during winter, so the capacity to cold-harden is required for temperate insects to survive overwintering (Lee, 1989). Two major strategies, freezeintolerance (or freeze-avoidance) and freeze-tolerance, are adopted by most overwintering insects (Baust \& Rojas, 1985; Storey \& Storey, 1988; Lee, 1989, 1991). Freeze-tolerant insects withstand the formation of internal ice and maintain a high supercooling point (SCP) through the production of ice nucleators (Storey \& Storey, 1988). Freeze-avoiding insects die upon freezing, but they often avoid lethal tissue freezing by lowering the SCP due to the evacuation of food residues in the gut and/or accumulation of sugars and polyols (Barson, 1974; Rickards et al., 1987; Pullin \& Bale, 1989; Bale \& Pullin, 1991). Recently, a third strategy of cryoprotective dehydration has been reported (Holmstrup et al., 2002; Sinclair et al., 2003 b), which might be adopted by some soil invertebrates (Holmstrup et al., 2002).

Cold hardiness or cold tolerance refers to the capacity of an organism to survive exposure to low temperature (Lee, 1989). Many temperate insects stop feeding and enter diapause before winter, reducing the loss of their reserves by lowering their metabolism and enhancing their cold hardiness (Denlinger, 1985, 1991; Tauber et al., 1986; Leather et al., 1993; Fields et al., 1998). Cold hardiness of insects can be improved through processes of cold acclimation (Salt, 1961) and rapid cold-hardening (Chen et al., 1987; Lee et al., 1987, 2006). For most cold acclimated insects the concentrations of low molecular weight polyols, sugars or amino acids increase during the acclimation period (Storey \& Storey, 1988; Lee \& Denlinger, 1991; Fields et al., 1998). As temperatures fluctuate, acclimation allows organisms to persist under conditions that would otherwise be lethal (Hoffmann, 1995). Insects increase their survival at lethal temperatures after pre-exposure to low (but non-lethal) temperatures, e.g., Cryptolestes ferrugineus (Fields et al., 1998).

Pine caterpillar, Dendrolimus tabulaeformis Tsai et Liu (Lepidoptera: Lasiocampidae), a major pine pest in the North China (Hou, 1987; Chen, 1990), enters diapause in the third or fourth instar in response to short day-length in fall. Diapausing larvae stop feeding and mostly overwinter on or under the soil surface or leaf litter of pine trees (Li \& Gia, 1989; Gia \& Li, 1991). Although previous studies examined the diapause characteristics of $D$. tabulaeformis, e.g. diapause induction (Li \& Gia, 1989; Gia \& Li, 1991), little is known about the mechanisms of cold hardiness and the overwintering strategy (Han et al., 2005). The supercooling capacity is increased and the water content decreased in diapausing larvae. A mean $\mathrm{SCP}$ of $-13.2^{\circ} \mathrm{C}$ was reported for diapausing larvae in the early stages of this species (Han et al., 2005). However, the minimum temperature in most of northern China is below $-14^{\circ} \mathrm{C}$ in winter. Hence, diapausing larvae of $D$.

\footnotetext{
* Corresponding author; e-mail: gef@ioz.ac.cn
} 


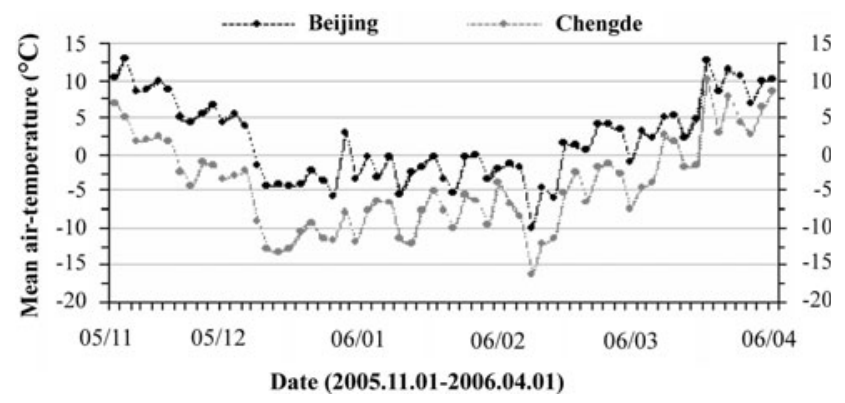

Fig. 1. Mean air-temperature in Beijing $\left(39^{\circ} \mathrm{N}, 116^{\circ} \mathrm{E}\right)$ and Chengde $\left(41^{\circ} \mathrm{N}, 117^{\circ} \mathrm{E}\right)$ during 1 November, 2005 to 1 April, 2006.

tabulaeformis may have adopted the strategy of freezetolerance or freeze-avoidance to survive in winter.

In order to elucidate the overwintering strategy of $D$. tabulaeformis we have examined: (1) Larval mortality in response to different temperature acclimations, (2) Effects of cold acclimation and de-acclimation on the survival (or $50 \%$ and $90 \%$ lethal time, $\mathrm{LT}_{50}$ and $\mathrm{LT}_{90}$ ) at $-14^{\circ} \mathrm{C}$, (3) Changes in the concentration of low molecular weight sugars (i.e. trehalose) in the haemolymph, and (4) The effect of temperature acclimation and de-acclimation on larval metabolic rate.

\section{MATERIAL AND METHODS}

\section{Insect}

Diapausing larvae of the pine caterpillar, D. tabulaeformis, were collected on November 10, 2005 in a forest of Chinese pine, Pinus tabulaeformis Carr., in Chengde $\left(\mathrm{CD} ; 41^{\circ} \mathrm{N}, 117^{\circ} \mathrm{E}\right)$, Hebei province. They were placed in plastic-net screen cages $(60 \times 60 \times 60 \mathrm{~cm})$ and transported by bus (without air-control operating) to Beijing (BJ; $\left.39^{\circ} \mathrm{N}, 116^{\circ} \mathrm{E}\right)$ in three hours. At that time, the air-temperature is $5-10^{\circ} \mathrm{C}$ in Beijing and Chengde (see Fig. 1 for climatic data). In a laboratory with a window $(2 \mathrm{~m} \times$ $1.5 \mathrm{~m}$ ) opening to the outside (40-60\% relative humidity at that time), the diapausing larvae were kept in $800 \mathrm{ml}$ glass-beakers covered by cotton cloth and plastic film (Han et al., 2005). After 1-2 $\mathrm{h}$, treatments were transferred into various temperatures in $10 \mathrm{~min}$, where light was excluded (Han et al., 2005; Huang et al., 2005).

\section{Acclimation at different temperatures}

Thirty to forty diapausing larvae were kept at 27, 18, 5, 0 and $-4^{\circ} \mathrm{C} \pm 1^{\circ} \mathrm{C}$ for $3,8,11,13,15,19,21,30,40$ or $45 \mathrm{~d}$ to determine mortality (Table 1). Treatments were kept in the dark with $50-60 \%$ RH. After determination of mortality larvae were not used again. As a control, diapausing larvae were kept under a $2 \mathrm{~cm}$-layer of garden soil with leaf litter in the field for various numbers of days, from November, 2005 to March, 2006 in Beijing (BJ; $\left.39^{\circ} \mathrm{N}, 116^{\circ} \mathrm{E}\right)$ (see Fig. 1 for climatic data) as the nonacclimated group. Each treatment was replicated two to four times.

\section{De-acclimation at 18 and $27^{\circ} \mathrm{C}$}

De-acclimation of insects has been defined as maintenance at a constant low temperature for a period of time followed by a transfer to another temperature above biological zero for a period of time (Šlachta et al., 2002). In order to examine the influence of de-acclimation on the cold hardiness of diapausing larvae, thirty to forty individuals acclimated at $0^{\circ} \mathrm{C}$ for 30 or 40 $\mathrm{d}$ were transferred to $18^{\circ} \mathrm{C}$ and $27^{\circ} \mathrm{C}$ for 2 days in darkness (Table 1). Each de-acclimation treatment was replicated two to four times.

\section{Exposure experiments at $-14^{\circ} \mathrm{C}$}

The $40 \mathrm{~d}$-acclimated or de-acclimated diapausing larvae (Table 1) were directly exposed to the lethal temperature of $-14^{\circ} \mathrm{C}$ for $0.5,1.5,3,5,10,24$ or $48 \mathrm{~h}$ in the dark, and then transferred to conditions of $27^{\circ} \mathrm{C}$ and $15.5 \mathrm{~L}: 8.5 \mathrm{D}$ for $24 \mathrm{~h}$ (Han et al., 2005). The numbers of live and dead larvae were recorded. Dead larvae were determined as those with no movement and exhibiting loose body segments (Goto et al., 2001). Recorded larvae were not reused, and larvae that died during acclimation were not included in the $-14^{\circ} \mathrm{C}$ exposure test. Each exposure period was replicated at least two times.

\section{Determination of supercooling points (SCP)}

Each larva was externally dried using filter paper, fixed with thermocouples connected to individual automatic temperature recorders (uR100, Model 4152, Yologama Electrical Co, Seoul, Korea), and placed into a Styrofoam tube $(5 \mathrm{~cm}$ length, $1 \mathrm{~cm}$ diameter) (Han et al., 2005). The thermocouple with the larva was placed inside an insulating Styrofoam box in the chamber to ensure that the cooling rate was about $1{ }^{\circ} \mathrm{C} / \mathrm{min}$ for recording the $\mathrm{SCP}$. The lowest temperature reached before an exothermic event occurred due to release of latent heat was regarded as the SCP (Zhao \& Kang, 2000). In determination, the tested larvae kept survival if drawn out from the freezing chamber once the SCP recorded, or they would be killed by the body-freezing

TABLE 1. Experimental scheme for acclimation (AC) and de-acclimation (DA) of diapausing larvae of D. tabulaeformis. The larvae were collected in the field and then transferred into different acclimation regimens $(\mathrm{N}=30-40 /$ treatment). Samples analyzed for supercooling points $(\mathrm{SCP})$ analysis and lower lethal temperature of $-14^{\circ} \mathrm{C}$ are indicated.

\begin{tabular}{|c|c|c|}
\hline Treatments & Transfer' Number of days (d) & Abbreviations \\
\hline Non-acclimated & Field $(C D)^{a} \rightarrow$ Field $(B J)^{\text {a }}$ for $3,8,11,13,15^{b}, 19,21,30^{b}, 40^{c}, 45 d$ & NA (field) \\
\hline \multirow{5}{*}{ Acclimated } & Field $(\mathrm{CD}) \rightarrow-4^{\circ} \mathrm{C}$ for $3,8,11,13,15^{\mathrm{b}}, 19,21,30^{\mathrm{b}}, 40^{\mathrm{c}}, 45 \mathrm{~d}$ & $\mathrm{AC}(-4)^{\circ} \mathrm{C}$ \\
\hline & Field $(\mathrm{CD}) \rightarrow 0^{\circ} \mathrm{C}$ for $3,8,11,13,15^{\mathrm{b}}, 19,21,30^{\mathrm{b}}, 40^{\mathrm{c}}, 45 \mathrm{~d}$ & $\mathrm{AC} 0^{\circ} \mathrm{C}$ \\
\hline & Field $(\mathrm{CD}) \rightarrow 5^{\circ} \mathrm{C}$ for $3,8,11,13,15^{\mathrm{b}}, 19,21,30^{\mathrm{b}}, 40^{\mathrm{c}}, 45 \mathrm{~d}$ & $\mathrm{AC} 5^{\circ} \mathrm{C}$ \\
\hline & Field $(\mathrm{CD}) \rightarrow 18^{\circ} \mathrm{C}$ for $3,8,11,13,15,19,21,30,40,45 \mathrm{~d}$ & $\mathrm{AC} 18^{\circ} \mathrm{C}$ \\
\hline & Field $(\mathrm{CD}) \rightarrow 27^{\circ} \mathrm{C}$ for $3,8,11,13,15,19,21,30,40,45 \mathrm{~d}$ & $\mathrm{AC} 27^{\circ} \mathrm{C}$ \\
\hline \multirow{2}{*}{ De-acclimated } & Field $(\mathrm{CD}) \rightarrow 0^{\circ} \mathrm{C}\left(\text { for } 30^{\mathrm{b}} \text { or } 40 \mathrm{~d}^{\mathrm{c}}\right)^{\prime} 18^{\circ} \mathrm{C}($ for $2 \mathrm{~d})$ & $\mathrm{DA} 18^{\circ} \mathrm{C}$ \\
\hline & Field $(\mathrm{CD}) \rightarrow 0^{\circ} \mathrm{C}\left(\right.$ for $30^{\mathrm{b}}$ or $\left.40 \mathrm{~d}^{\mathrm{c}}\right), 27^{\circ} \mathrm{C}(\text { for } 2 \mathrm{~d})^{\mathrm{b}}$ & $\mathrm{DA} 27^{\circ} \mathrm{C}$ \\
\hline
\end{tabular}

${ }^{a} \mathrm{CD}-$ Chengde $\left(41^{\circ} \mathrm{N}\right), \mathrm{BJ}-$ Beijing $\left(39^{\circ} \mathrm{N}\right) ;{ }^{\mathrm{b}} \mathrm{SCP}$ analysis; ${ }^{\mathrm{c}}$ Exposure to $-14^{\circ} \mathrm{C}$. 


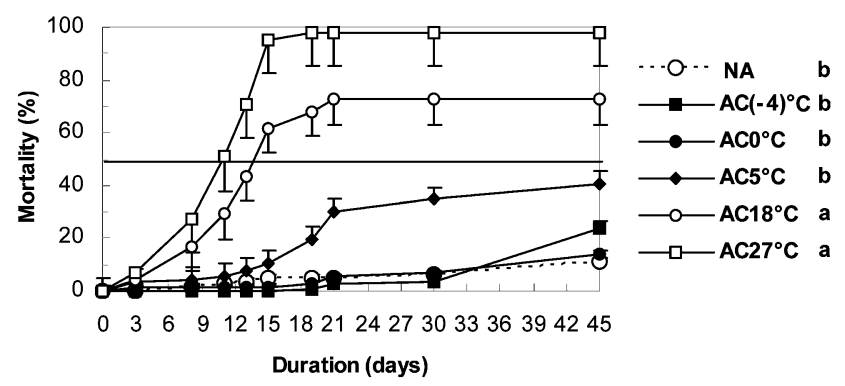

Fig. 2. Corrected mortality (mean $\pm \mathrm{SE}$ ) in the diapausing larvae of D. tabulaeformis after various days in the field (NA) and during different acclimations (AC). Different lower case letters represent a significant difference in total mortality after 45 days (ANOVA: $\mathrm{F}=33.286$, d.f. $=5,9, \mathrm{P}<0.001$, followed by Tukey's HSD at $\mathrm{P}<0.05)$.

incidence if persisting in the chamber beyond fifteen seconds or so after the SCP recorded. The live larvae were examined to determine concentrations of low molecular weight sugars in their haemolymph and analyzed based on their SCP status: low group ( $\mathrm{LG}, \mathrm{SCP} \leq-14^{\circ} \mathrm{C}$ ) or high group (HG, $\left.\mathrm{SCP}>-14^{\circ} \mathrm{C}\right)$.

\section{Low molecular weight sugar measurements}

Five to eight healthy individuals of diapausing larvae, with three replicates, were used for the extraction of larval haemolymph. Larval haemolymph was collected using a capillary glass tube after removing one or two pro-legs (Han et al., 2005). Exudates were centrifuged at 2,500 $\mathrm{g}$ for $10 \mathrm{~min}$ at $4{ }^{\circ} \mathrm{C}$, and then supernatants were subjected to high-performance anion exchange chromatography with pulsed amperometric detection (HPAE-PAD) by using a Dionex ICS-2500 ion chromatograph equipped with a Carbopac PA-1 analytical column and a Carbopac PA-1 guard column. Carbohydrates were eluted at a flow rate of $1.0 \mathrm{ml}$ per min at 1,400 psi with $100 \mathrm{mM} \mathrm{NaOH}$ for 35 min (Liu et al., 2005). Carbohydrates were quantified using authentic standard sugars (Sigma, a company).

\section{Respiration measurements}

Oxygen uptake was measured in a Gilson Differential Respirometer (Gilson, 1963) using methods adapted from Daniel \& Smith (1994), Guedes et al. (2003) and Gao et al. (2008). A series of $13 \mathrm{ml}$ flasks was used for each measurement, with each flask containing 1 to 2 diapausing larvae that had been dried using filter paper. Larvae were allowed to adapt to the flask environment for five to $10 \mathrm{~min}$ at $20 \pm 1{ }^{\circ} \mathrm{C}$ and a small filter paper wick with $0.30 \mathrm{ml}$ alkali solution $(10 \% \mathrm{KOH})$ was placed in the centre of the flask for $\mathrm{CO}_{2}$ absorption. The changes in volume of gas represented oxygen uptake, which was read by manometric adjustments with a micrometer scale. Readings were taken every $10 \mathrm{~min}$ over $30 \mathrm{~min}$ and the last barometric pressure readings were used to convert the respirometer volume changes to standard temperature and pressure conditions (Daniel $\&$ Smith, 1994). Before each measurement larvae were weighed using an electronic balance (sensitivity: $0.1 \mathrm{mg}$, Sartorius, R200 D.A.G., Göttingen, Gernamy). The respiration rate was calculated as the amount of $\mathrm{O}_{2}$ uptake per fresh weight per hour $(\mu 1$ $\mathrm{O}_{2} / \mathrm{mg} / \mathrm{h}$ ) (Daniel \& Smith, 1994; Guedes et al., 2003; Gao et al., 2008). Each measurement was replicated six times.

\section{Statistical analysis}

Distribution of SCP is often bimodal (Spicer \& Gaston, 1999). Cannon \& Block (1988) discussed the separation of bimodal SCP distributions into high (freeze at higher subzero temperatures) and low (freeze at lower subzero temperatures) groups. However, the breakpoints in bimodal distributions are

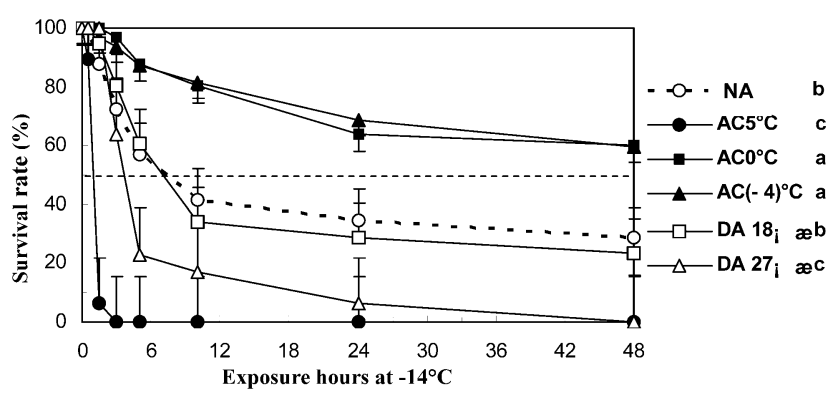

Fig. 3. Survival rate (mean $\pm \mathrm{SE}$ ) in non-acclimated (NA), acclimated (AC) and de-acclimated (DA) diapausing larvae of D. tabulaeformis during exposure to $-14^{\circ} \mathrm{C}$ for $48 \mathrm{~h}$. Different lower case letters represent significant differences in survival after 48 h (ANOVA: $F=93.271$, d.f. $=5,12, \mathrm{P}<0.001$, followed by Tukey's HSD at $\mathrm{P}<0.05$ ).

often determined arbitrarily, depending on the supercooling characteristics of the species studied and visual assessment of a histogram for an obvious break (Block \& Sømme, 1982; Worland \& Convey, 2001; Sinclair et al., 2003b; Chen \& Kang, 2005). The mean SCP of the control group (NA, see Table 1) in the study was $-13.5^{\circ} \mathrm{C} \pm 0.73$ (Mean $\pm \mathrm{SE}$ ). Using a break point of $-14^{\circ} \mathrm{C}$, individuals were classed into a Low group (LG, SCP $\leq-14 \mathrm{C}$ ) or High group (HG, SCP $>-14 \mathrm{C}$ ). Three patterns of frequency distribution of SCP were defined as LG pattern ( $>60 \%$ of individuals in LG), LG-HG pattern $(<60 \%$ of individuals in $\mathrm{LG}$ and $\mathrm{HG})$ and $\mathrm{HG}$ pattern ( $>60 \%$ of individuals in HG).

All survival or mortality data were expressed as the corrected percentage of diapausing larvae using two calculations

Corrected percentage mortality $=$

$$
\frac{\text { Survival of control-survival of treatment }}{\text { Survival of control }} \times 100
$$

Corrected percentage survival $=1-$ Corrected percentage mortality

adapted from Zhao \& Kang (2000). T-test of mean values and one-way analysis of variance (ANOVA) was used for data analysis, and Tukeys Honest Significant Difference test procedure was used to make multiple comparisons. The amount of time (95\% fiducial limits) necessary to achieve 50\% and $90 \%$ mortality $\left(\mathrm{LT}_{50}\right.$ and $\left.\mathrm{LT}_{90}\right)$ in a given time period was estimated by Probit analysis (see Wang \& Kang, 2005) using SPSS software. The percentage data were arcsine transformed before analysis, and untransformed data were presented.

\section{RESULTS}

\section{Mortality of diapausing larvae acclimated at different temperatures}

Significant differences in mortality rates were observed after acclimation treatments for 45 days (ANOVA: $\mathrm{F}=$ 33.286, d.f. $=5,9, \mathrm{P}<0.001$ ) (Fig. 2). Acclimation at high temperatures, such as $18^{\circ} \mathrm{C}\left(\mathrm{AC} 18^{\circ} \mathrm{C}\right)$ and $27^{\circ} \mathrm{C}$ $\left(\mathrm{AC} 27^{\circ} \mathrm{C}\right)$, had a significantly higher total mortality after 45 days than the NA group. The time that it took to kill $50 \%\left(\mathrm{LT}_{50}\right)$ or $90 \%\left(\mathrm{LT}_{90}\right)$ was $10.6 \mathrm{~d}$ and $14.4 \mathrm{~d}$ respectively in $\mathrm{AC} 27^{\circ} \mathrm{C}$, and the $\mathrm{LT}_{50}$ was $14.5 \mathrm{~d}$ in $\mathrm{AC} 18^{\circ} \mathrm{C}$, all significantly higher than other groups. Although no significant differences were observed among the NA, $\mathrm{AC}(-4)^{\circ} \mathrm{C}$ (acclimated at $-4^{\circ} \mathrm{C}$ ), $\mathrm{AC} 0^{\circ} \mathrm{C}$ (acclimated at $0^{\circ} \mathrm{C}$ ) and $\mathrm{AC} 5^{\circ} \mathrm{C}$ (acclimated at $5^{\circ} \mathrm{C}$ ) groups after 45 


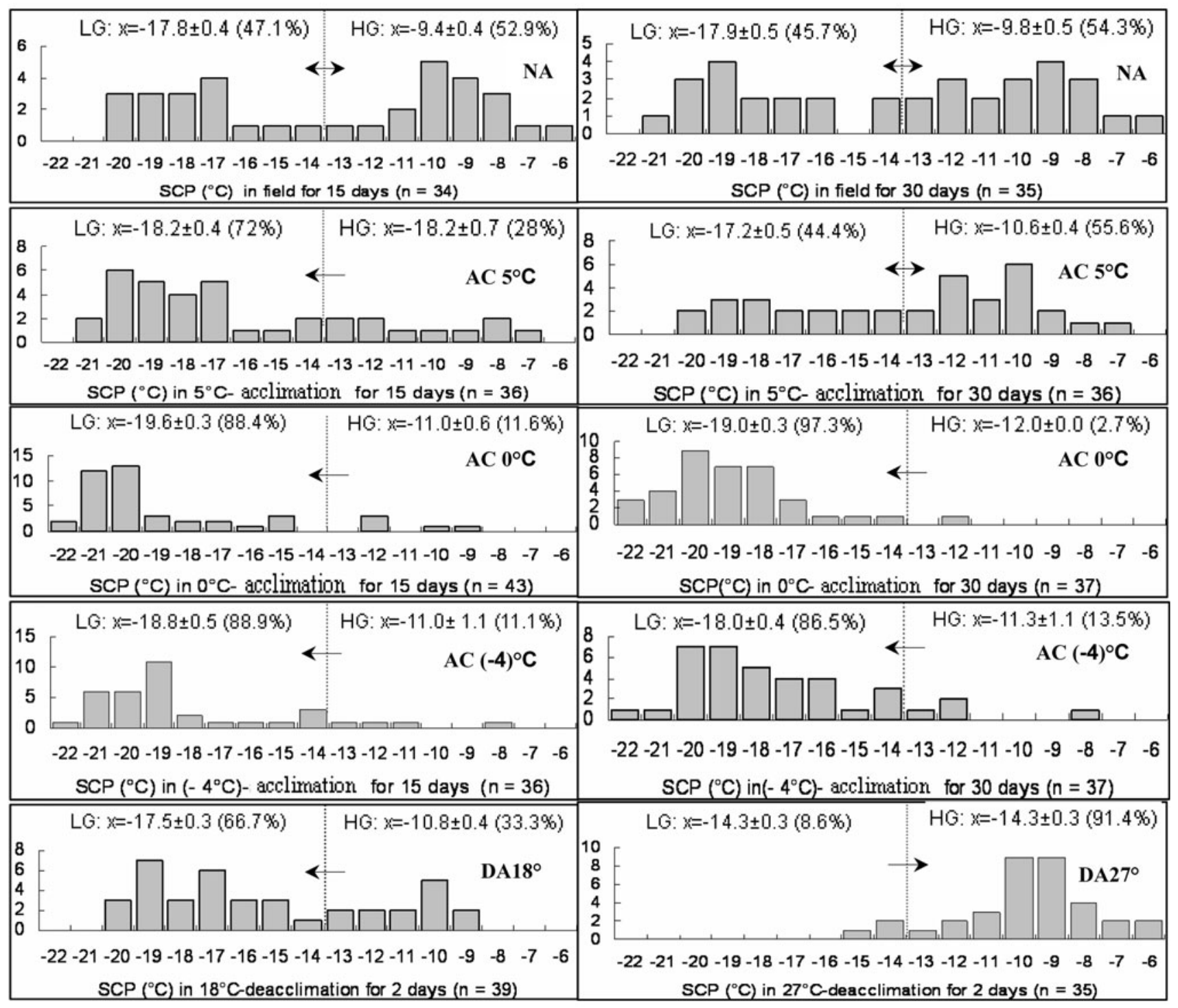

Fig. 4. Bimodal frequency distribution of SCP in diapausing larvae of D. tabulaeformis showing differences between nonacclimated (NA), acclimated (AC) and de-acclimated (DA) diapausing larvae. The break point is designated at $-14^{\circ} \mathrm{C}$ between $\mathrm{High}$ group ( $\mathrm{HG}$; $\mathrm{SCP}>-14^{\circ} \mathrm{C}$ ) and Low group $\left(\mathrm{LG}\right.$; $\left.\mathrm{SCP} \leq-14^{\circ} \mathrm{C}\right)$. The number of individuals tested (n), mean value of SCP (mean \pm $\mathrm{SE})$ and the percentage in $\mathrm{HG}$ or LG are indicated in the figure. Acclimation/de-acclimation shows a shift in the bimodal pattern as indicated by arrows; LG ( $>60 \%$ of individuals in LG, left arrow), LG-HG $(<60 \%$ of individuals in LG and HG, dual-direction arrow) and $\mathrm{HG}$ pattern ( $>60 \%$ of individuals in $\mathrm{HG}$, right arrow).

days, an increase in mortality was observed in $\mathrm{AC} 5^{\circ} \mathrm{C}$ (Fig. 2). The $\mathrm{LT}_{50}$ in $\mathrm{NA}, \mathrm{AC}(-4)^{\circ} \mathrm{C}, \mathrm{AC}^{\circ} \mathrm{C}$ and $\mathrm{AC} 5^{\circ} \mathrm{C}$ were all beyond 45 days.

\section{Survival of diapausing larvae at $-14^{\circ} \mathrm{C}$}

The corrected survivorship showed some significant differences between $\mathrm{NA}, \mathrm{AC}(-4)^{\circ} \mathrm{C}, \mathrm{AC} 0^{\circ} \mathrm{C}, \mathrm{AC} 5^{\circ} \mathrm{C}$, $\mathrm{DA} 18^{\circ} \mathrm{C}$ and $\mathrm{DA} 27^{\circ} \mathrm{C}$ groups exposed to the temperature of $-14^{\circ} \mathrm{C}$ for $48 \mathrm{~h}$ (ANOVA: $\mathrm{F}=93.271$, d.f. $=5,12, \mathrm{P}<$ 0.001 ) (Fig. 3). Survival in $\mathrm{AC}(-4)^{\circ} \mathrm{C}$ and $\mathrm{AC} 0^{\circ} \mathrm{C}$ groups was significantly higher than in other groups, and their $\mathrm{LT}_{50}$ values were both above $48 \mathrm{~h}$. The $\mathrm{DA} 18^{\circ} \mathrm{C}$ group had the similar survival to the NA group. The $\mathrm{LT}_{50}$ was $7.6 \mathrm{~h}$ and $8.4 \mathrm{~h}$ respectively in DA $18^{\circ} \mathrm{C}$ and NA group. The DA2 $7^{\circ} \mathrm{C}$ and $\mathrm{AC} 5^{\circ} \mathrm{C}$ had the lowest survival when exposed to $-14^{\circ} \mathrm{C}$. The $\mathrm{LT}_{50}$ and $\mathrm{LT}_{90}$ were only $4.1 \mathrm{~h}$ and
$12.7 \mathrm{~h}$ respectively in $\mathrm{DA} 27^{\circ} \mathrm{C}$. However, in the case of $\mathrm{AC} 5^{\circ} \mathrm{C}$, the $\mathrm{LT}_{90}$ was below $1.5 \mathrm{~h}$ (Fig. 3 ).

\section{The supercooling points (SCP) and their distribution pattern}

The SCP of diapausing larvae in NA groups exhibited a bimodal distribution with the break point value of $-14^{\circ} \mathrm{C}$. The SCP ranged from $-6^{\circ} \mathrm{C}$ to $-22^{\circ} \mathrm{C}$ (Fig. 4). The two NA groups had a LG-HG pattern, which also occurred in the group of $\mathrm{AC} 5^{\circ} \mathrm{C}$ after 30 days. The $\mathrm{LG}$ pattern was observed in the $\mathrm{AC}(-4)^{\circ} \mathrm{C}, \mathrm{AC} 0^{\circ} \mathrm{C}, \mathrm{DA} 18^{\circ} \mathrm{C}$ groups as well as in the $\mathrm{AC} 5^{\circ} \mathrm{C}$ group after 15 days. However, DA $27^{\circ} \mathrm{C}$ group had a HG pattern (Fig. 4). The mean SCP ranged from $-19.6 \pm 0.3^{\circ} \mathrm{C}$ to $-14.3 \pm 0.3^{\circ} \mathrm{C}$ in $\mathrm{LG}$, but from $-12.0 \pm 0.0^{\circ} \mathrm{C}$ to $-9.4 \pm 0.4^{\circ} \mathrm{C}$ in $\mathrm{HG}$ in the NA, 
TABLE 2. Concentration (mean $\pm \mathrm{SE}$ ) of trehalose, galactose, glucose and mannose in the haemolymph of diapausing larvae of $D$. tabulaeformis with supercooling point frequency distribution in High group (HG; $\mathrm{SCP}>-14^{\circ} \mathrm{C}$ ) and Low group (LG; SCP $\leq$ $-14^{\circ} \mathrm{C}$ ). Different lower case letters (a vs. b) represent a significant difference between concentration of trehalose versus galactose, glucose and mannose (ANOVA: $\mathrm{F}=128.285$, d.f. $=3,8, \mathrm{P}<0.001$ for $\mathrm{LG} ; \mathrm{F}=360.463$, d.f. $=3,12, \mathrm{P}<0.001$ for HG, followed by Tukey's HSD at $\mathrm{P}<0.05$ ). Different capital letters (A vs. B) represent a significant difference in concentration between HG and LG (by t-test).

\begin{tabular}{lcccccr}
\hline \multirow{2}{*}{ Sugar } & \multicolumn{2}{c}{ Concentration $(\mathrm{mg} / \mathrm{ml})$} & & \multicolumn{3}{c}{ LG vs. HG } \\
\cline { 2 - 3 } \cline { 5 - 6 } & $\mathrm{LG}$ & $\mathrm{HG}$ & $\mathrm{t}$ & $\mathrm{t}$ d.f. & Sig. (2-tailed) \\
\hline Trehalose & $17.6 \pm 1.4 \mathrm{Aa}$ & $8.3 \pm 0.4 \mathrm{Ba}$ & & 7.219 & 5 & 0.001 \\
Galactose & $1.3 \pm 0.1 \mathrm{Ab}$ & $0.0 \pm 0.0 \mathrm{Bb}$ & & 21.392 & 5 & $<0.001$ \\
Glucose & $0.6 \pm 0.1 \mathrm{Ab}$ & $0.2 \pm 0.1 \mathrm{Bb}$ & & 12.474 & 5 & $<0.001$ \\
Mannose & $1.8 \pm 0.3 \mathrm{Ab}$ & $0.4 \pm 0.1 \mathrm{Bb}$ & & 5.518 & 5 & 0.003 \\
\hline
\end{tabular}

$\mathrm{AC}(-4)^{\circ} \mathrm{C}, \quad \mathrm{AC} 0{ }^{\circ} \mathrm{C}, \quad \mathrm{AC} 5^{\circ} \mathrm{C}, \quad \mathrm{DA} 18^{\circ} \mathrm{C}$ and $\mathrm{DA} 27^{\circ} \mathrm{C}$ groups (Fig. 4).

\section{Low molecular weight sugars in haemolymph of diapausing larvae}

Four low molecular weight sugars (trehalose, galactose, glucose and mannose) were detected in the haemolymph of diapausing larvae of $D$. tabulaeformis. Trehalose was the major sugar detected in the haemolymph of either LG or HG individuals; concentration was $17.6 \mathrm{mg} / \mathrm{ml}$ in LG and $8.3 \mathrm{mg} / \mathrm{ml}$ in $\mathrm{HG}$, both of which were significantly higher than levels of galactose, glucose and mannose (ANOVA: $\mathrm{F}=128.285$, d.f. $=3,8, \mathrm{P}<0.001$ for $\mathrm{HG}$; $\mathrm{F}=$ 360.463 , d.f. $=3,12, \mathrm{P}<0.001$ for $\mathrm{LG}$, Table 2). The concentrations of trehalose, glucose and mannose were all significantly different between the LG and HG groups. The trend for all sugars consistently pointed to a significantly higher concentration in the haemolymph of LG individuals with lower SCPs (Table 2). Moreover, no galactose was detected in the HG group, though a higher concentration of galactose $(1.3 \mathrm{mg} / \mathrm{ml})$ was detected in the LG group.

\section{Respiration rate in diapausing larvae acclimated or de-acclimated at different temperatures}

Significant differences in $\mathrm{O}_{2}$ uptake were detected between $\mathrm{NA}, \mathrm{AC}(-4)^{\circ} \mathrm{C}, \mathrm{AC} 0^{\circ} \mathrm{C}, \mathrm{AC} 5^{\circ} \mathrm{C}, \mathrm{DA} 18^{\circ} \mathrm{C}$ and

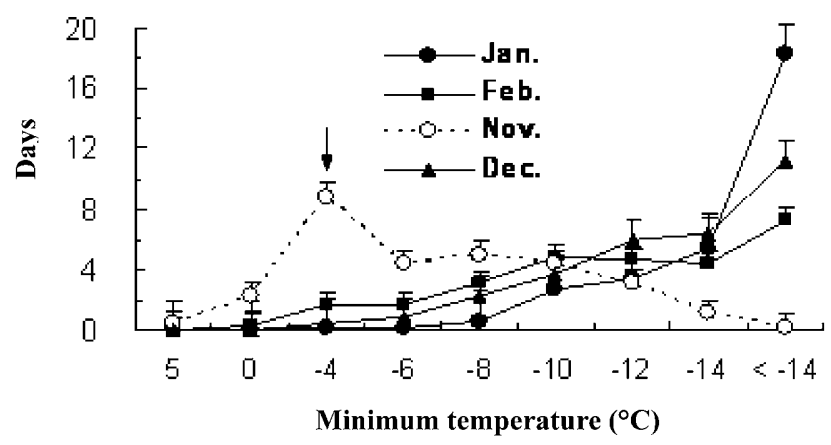

Fig. 5. Number of days (mean $\pm \mathrm{SE}$ ) of minimum airtemperature below $5^{\circ} \mathrm{C}$ in November (Nov.), December (Dec.), January (Jan.) and February (Feb.) in Chengde $\left(41^{\circ} \mathrm{N}\right)$ during 1995-2006. Arrows represent the critical periods of acclimation temperatures (black arrow) and periods of lethal temperatures (grey arrow) during the diapause of larval pine caterpillar, $D$. tabulaeformis, in the field.
DA $27^{\circ} \mathrm{C}$ groups (ANOVA: $\mathrm{F}=14.45$, d.f. $=5,31, \mathrm{P}<$ 0.001 ) (Fig. 6). The DA $18^{\circ} \mathrm{C}$ and $\mathrm{DA} 27^{\circ} \mathrm{C}$ treatments had the highest respiration rate levels (1.0 and $1.31 / \mathrm{mg} / \mathrm{h}$ ) compared with other groups. The respiration rate was significantly higher in NA group $(0.81 / \mathrm{mg} / \mathrm{h})$ than in three $\mathrm{AC}$ groups: $\mathrm{AC}(-4)^{\circ} \mathrm{C}, \quad \mathrm{AC} 0^{\circ} \mathrm{C}$ and $\mathrm{AC} 5^{\circ} \mathrm{C}$. The $\mathrm{AC}(-4)^{\circ} \mathrm{C}$ and $\mathrm{AC} 0^{\circ} \mathrm{C}$ groups had the same lowest rate of $\mathrm{O}_{2}$ uptake (0.11/ mg / h) (Fig. 6).

\section{DISCUSSION}

\section{Overwintering strategy and the supercooling point (SCP)}

Most overwintering insects in temperate climates are thought to be freeze-intolerant, relying on the process of supercooling to lower their supercooling points (SCPs) (Bale, 1991). The SCP is a valid measurement of the lower lethal temperature. It is correlated with the level of cold tolerance for many insect species (Worland \& Convey, 2001; Klok et al., 2003; Sinclair et al., 2003a). In this study, D. tabulaeformis could not be freeze-tolerant as is evident from its body-freezing profile in SCP determinations. Its cold hardiness was enhanced through depression of the SCP. Basing on the original two strategies, freeze-tolerance and freeze-avoidance, Bale (1996) proposed that insects could be conveniently classified into five groups representing a continuum from the most to the least cold-hardy. They are freeze-tolerant, freeze-avoidant (only including those species in which there is little or no low-temperature mortality in the absence of freezing),

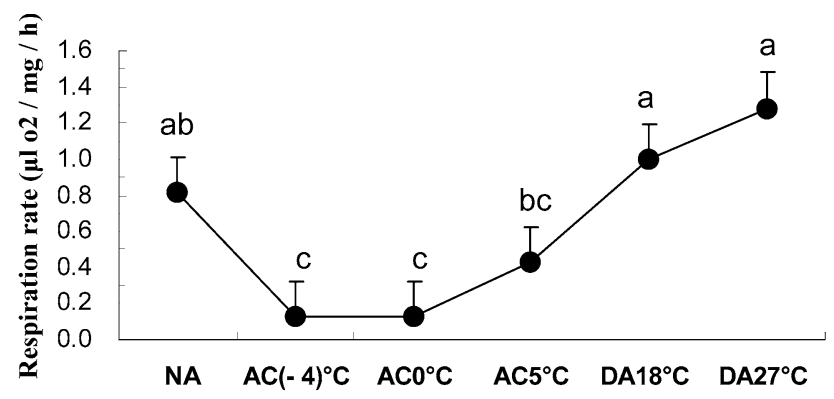

Fig. 6. Respiration rate (mean $\pm \mathrm{SE}$ ) of non-acclimated (NA), acclimated (AC) and de-acclimated (DA) larvae. Different letters represent a significant difference in respiration rate (ANOVA: $\mathrm{F}=14.45$, d.f. $=5,31, \mathrm{P}<0.001$; followed by Tukey's HSD at $\mathrm{P}<0.05)$. 
chill tolerant, chill susceptible and opportunistic survival (Bale, 1996, 2002). Our results show that D. tabulaeformis might belong to the chill tolerant group. It adopted the strategy of depressing SCP to enhance its cold hardiness, and could be tolerant of low temperatures (i.e. $-14^{\circ} \mathrm{C}$ ). However, mortality occurred above SCP, and became apparent with increasing periods of low temperature exposure (Fig. 3). At the time of entering diapause, the SCP of larvae was maximally depressed by $7^{\circ} \mathrm{C}$ compared with that of non-diapause larvae, and the survival rates were significantly higher than the latters when exposed to lower lethal temperatures (e.g. $-10,-17^{\circ} \mathrm{C}$ etc.) for minutes or hours (Han et al., 2005). After acclimation at low temperatures in advance, such as at $-4^{\circ} \mathrm{C}$ or $0^{\circ} \mathrm{C}$ for 15 to 30 days, the SCP of the diapausing larvae was significantly lowered, and at the same time the cold hardiness was increased when placed at $-14^{\circ} \mathrm{C}$ compared with the non-acclimated larvae.

Within a population, the SCP shows substantial variation, with a frequency distribution that is often clearly bimodal (Sømme \& Block, 1982; Klok \& Chown, 1998; Chen \& Kang, 2005; Worland et al., 2006). Such variation is attributed directly to adaptive responses to changing environmental conditions (Block, 1990), and these bimodal SCP distributions might represent a bethedging strategy that would allow animals to survive unexpected cold snaps (Klok \& Chown, 1998). However, the reasons why the variable and/or bimodal SCP distributions occur remain poorly understood (Worland et al., 2006). In the diapausing larvae of $D$. tabulaeformis, the SCP ranged from $-6.0^{\circ} \mathrm{C}$ to $-22.0^{\circ} \mathrm{C}$, and its frequency distribution was also bimodal with shift to and from LG vs. HG group influenced by cold acclimation and deacclimation. For instance, an LG-HG pattern of the nonacclimated larvae could be changed into a LG pattern when acclimated at low temperatures, such as $-4^{\circ} \mathrm{C}$ or $0^{\circ} \mathrm{C}$ for 15 to 30 days, but then would be transformed into a HG pattern when de-acclimated at high temperatures, such as at $27^{\circ} \mathrm{C}$ for only two days (see Fig. 4).

The SCP variable can be correlated with a variety of factors, such as starvation (Sømme \& Block, 1982; Leinaas \& Sømme, 1984; Leinaas \& Fjellberg, 1985; Worland \& Block, 1999), moulting (Worland et al., 2006) and undergoing a range of biochemical changes that include the production of cryoprotectants (Chown \& Nicolson, 2004). In most insects, the levels of low molecular weight polyols, sugars or amino acids, such as glycerol, sorbitol, trehalose, sucrose, proline and alanine tend to increase when larvae undergo a cold-acclimation (Storey \& Storey, 1988; Lee \& Denlinger, 1991; Fields et al., 1998). However, they return to their pre-acclimation levels after a de-acclimation, as documented for trehalose and proline in Cryptolestes ferrugineus (Fields et al., 1998). In our results, the levels of trehalose, glucose, mannose and galactose in the haemolymph of diapausing larvae were correlated with the SCP variable as well as the degree of cold hardiness. Levels of the four low molecular sugars were all higher in LG larvae than in HG larvae. This suggests that cold acclimation increased the cold hardiness of the diapausing larvae through depressing the SCP, while de-acclimation did the reverse. The SCP variable was positively correlated to the levels of trehalose, glucose, mannose and galactose in the haemolymph, while these levels were negatively correlated to the metabolic rate. For instance, the increased rate of metabolism after de-acclimation at high temperature, such as $27^{\circ} \mathrm{C}$, led to a decrease in the level of these low molecular weight sugars. Conversely, the low levels of metabolism after cold acclimation, such as at $-4^{\circ} \mathrm{C}$ or $0^{\circ} \mathrm{C}$, maintained high levels of these sugars.

\section{Effects of acclimation and de-acclimation on cold hardiness and mortality}

Organisms, such as bacteria, plants, and animals, can increase their survival to otherwise lethal stressful environmental conditions by prior exposure to non-lethal but stressful conditions. This ability to acclimate is considered to be an adaptive response to changing environmental conditions (Hofmann, 1995). The diapausing larvae of $D$. tabulaeformis, had the ability to become acclimated at low temperatures, such as at $0^{\circ} \mathrm{C}$ and $-4^{\circ} \mathrm{C}$ for 15 or 30 days. The cold acclimation improved their ability to survive at $-14^{\circ} \mathrm{C}$, as shown by the $\mathrm{LT}_{50}$ in $\mathrm{AC}(-4)^{\circ} \mathrm{C}$ and $\mathrm{AC} 0^{\circ} \mathrm{C}$ above $48 \mathrm{~h}$, both significantly higher than the $8.4 \mathrm{~h}$ in NA. In the field, seasonal acclimation could increase survival in adverse conditions, such as cold shocks in winter. During 1995-2006, in North China the temperatures decreased rapidly once autumn commenced, and the minimum temperatures were always below $-14^{\circ} \mathrm{C}$ (Fig. 5), the lower lethal temperature for the diapausing larvae. However, cold acclimation in advance at some non-lethal low temperature in autumn might improve the tolerance of the diapausing larvae to the lower lethal temperatures later in winter. Fig. 5 shows a prolonged period (several weeks) with minimum temperatures between $-4^{\circ} \mathrm{C}$ and $0^{\circ} \mathrm{C}$ in November in Chengde. After undergoing this period of cold acclimation most diapausing larvae would survive the following cold shock through December to February. Consequently, the pine forest can be damaged again in spring as severely as during the preceding summer after diapause termination of D. tabulaeformis (unpubl. data).

Interestingly, cold acclimation was lost in a short time following de-acclimation (i.e., $27^{\circ} \mathrm{C}$ for two days) of diapausing larvae of $D$. tabulaeformis. Results showed that the $\mathrm{LT}_{50}$ and $\mathrm{LT}_{90}$ were decreased significantly to $4.1 \mathrm{~h}$ and $12.7 \mathrm{~h}$ in DA2 $7^{\circ} \mathrm{C}$. The loss of cryoprotectants, such as trehalose, glucose, mannose and galactose in haemolymph, because of the rapidly increasing metabolism during de-acclimation, might be a major reason for the loss of cold acclimation in the de-acclimated larvae. Similar results were also found in Cryptolestes ferrugineus (Fields et al., 1998). Most insects could be prevented from dying during a warm winter, but the cold acclimation would be lost during a prolonged acclimation at above zero temperature (i.e. $5^{\circ} \mathrm{C}$ in D. tabulaeformis). Moreover, the cold acclimation might be decreased during de-acclimation in warm days. So when cold shocks occurred following the warm days, the overwin- 
tering insect would be killed a lot for the loss of cold hardiness, such as in the case of diapausing larvae of $D$. tabulaeformis.

Acclimation itself can be fitness decreasing (Hofmann, 1995). In the diapausing larvae of $D$. tabulaeformis, acclimation at high temperatures, such as $18^{\circ} \mathrm{C}$ and $27^{\circ} \mathrm{C}$, increased mortality rapidly during the acclimation. It might be the consequence of a rapid loss of energy at high temperatures as metabolic rate increases. However, the acclimation at temperatures close to $0^{\circ} \mathrm{C}$, such as at $5^{\circ} \mathrm{C}$ or $-4^{\circ} \mathrm{C}$ was more complicated. Shorter than 15-day acclimation at $5^{\circ} \mathrm{C}$ can increase cold tolerance (Fig. 4), which, however, can be lost rapidly with the loss of cryoprotectants (Ring, 1982) during longer acclimation at $5^{\circ} \mathrm{C}$. For instance, the $\mathrm{LT}_{90}$ was below $1.5 \mathrm{~h}$ in $\mathrm{AC}^{\circ} \mathrm{C}$ after a 40 d-acclimation. Mortality did not increase significantly when acclimated at $0^{\circ} \mathrm{C}$ or $-4^{\circ} \mathrm{C}$, but chilling injury took place, especially at $-4^{\circ} \mathrm{C}$, during the prolonged period (e.g. above $45 \mathrm{~d}$ ) of acclimation, because of the detrimental changes in membrane viscosity, enzyme activity or ionic concentrations (Fields et al., 1998).

In conclusion, the diapausing larvae of $D$. tabulaeformis were chill tolerant insects according to Bales system (Bale, 1996). They adopted the strategy of depressing the SCP through accumulation or production of cryoprotectants, such as trehalose, glucose, mannose, galactose, to enhance their cold hardiness. Bimodal frequency distribution of SCP was demonstrated in the diapausing larvae, but the bimodality changed into three patterns, LG, LG-HG and HG pattern, in response to cold acclimation and de-acclimation. Overall, the degree of cold hardiness could be ranked as: $\mathrm{LG}>\mathrm{LG}-\mathrm{HG}>\mathrm{HG}$. The level of metabolism could affect the LG-HG frequency distribution of SCPs through suppressing the levels of trehalose, glucose, mannose, and galactose. The ability of larvae to cold acclimate at non-lethal temperatures in autumn could be an adaptive strategy to avoid the cold shocks in winter. Apropos, acclimation in warm conditions or a long-term acclimation at temperatures above $0^{\circ} \mathrm{C}$ could increase their mortality through elevation of the lower lethal temperatures. Chill injury could also affect the diapausing larvae after a long-term cold acclimation.

ACKNOWLEDGEMENTS. We thank M. Harris from Texas A\&M University for improving English, and are grateful to B. Chen from Institute of Zoology, CAS, X.-P. Wang from Huazhong Agricultural University, and R.-D. Han from Wei Fang College of Science and Technology for their critical reading and helpful comments on an earlier version of the manuscript. Grateful thanks are expressed to Q.-S. Liu from Central Laboratory, Feed Research Institute of Chinese Academic of Agricultural Sciences for his excellent technical assistance in HPAG-PAD. Climatic data are from the China Meteorological Office. The research is supported by funds from the Key Program of National Natural Science Foundation of China (30330490).

\section{REFERENCES}

BALE J.S. 1991: Insects at low temperature: a predictable relationship? Funct. Ecol. 5: 291-298.
BALE J.S. 1996: Insects cold hardiness: a matter of life and death. Eur. J. Entomol. 93: 369-382.

BALE J.S. 2002: Insects and low temperatures: from molecular biology to distributions and abundance. Phil. Trans. R. Soc. Lond. (B) 357: 849-862.

Bale J.S. \& Pullin A.S. 1991: Opportunities and risks in the overwintering strategy of a wall-dwelling species of Hypogastrura (Collembola). CryoLetters 12: 155-162.

BARSON G. 1974: Some effects of freezing temperatures on overwintering larvae of the large elm bark beetle (Scolytus scolytus). Ann. Appl. Biol. 78: 219-224.

BAUST J.G. \& RoJAS R.R. 1985: Insect cold hardiness: facts and fancy. J. Insect Physiol. 31: 755-759.

BLOCK W. 1990: Cold tolerance of insects and other arthropods. Phil. Trans. R. Soc. Lond. (B) 326: 613-633.

Block W. \& Sømme L. 1982: Cold hardiness of terrestrial mites at Signy Island, Maritime Antarctic. Oikos 38: 157-167.

CANNON R.J.C. \& Block W. 1988: Cold tolerance of microarthropods. Biol. Rev. 63: 23-77.

Chen C.J. 1990: Integrated Management of Pine Caterpillars in China. China Forestry Publishing House, Beijing, 401 pp. [in Chinese].

Chen B. \& KANG L. 2005: Can greenhouses eliminate the development of cold resistance of the leaf-miners? Oecologia 144: $187-195$.

Chen C.P., Denlinger D.L. \& Lee JR. R.E. 1987: Cold-shock injury and rapid cold hardening in the flesh fly Sarcophaga crassipalpis. Physiol. Zool. 60: 297-304.

Chown S.L. \& Nicolson S.W. 2004: Insect Physiological Ecology. Mechanisms and Patterns. Oxford University Press, Oxford, $254 \mathrm{pp}$.

Daniel S.H. \& Smith R.H. 1994: Functional anatomy of the egg pore in Callosobruchus maculates: a trade-off between gas exchange and protective functions? Physiol. Entomol. 19: 30-38.

DENLINGER D.L. 1985: Hormonal control of diapause. In Kerkut G.A. \& Gilbert L.T. (eds): Comprehensive Insect Physiology Biochemistry and Pharmacology. Vol. 8. Pergamon Press, Oxford, pp. 353-412.

DenLINGER D.L. 1991: Relationship between cold hardiness and diapause. In Lee Jr. R.E. \& Denlinger D.L. (eds): Insects at Low Temperature. Chapman and Hall, New York, pp. 174-198.

Fields P.G., Fleurat-Lessard F., Lavenseau L., Febvay G., Peypelut L. \& Bonnot G. 1998: The effect of cold acclimation and deacclimation on cold tolerance, trehalose and free amino acid levels in Sitophilus granaries and Cryptolestes ferugineus (Coleoptera). J. Insect Physiol. 44: 955-965.

GaO F., Ge F., Liu X.H. \& Song Y. 2008: Impact of insecticides on the structure and productivity of insect pest and natural enemy communities associated with intercropping in cotton agroecosystems. Int. J. Pest. Manag. 54: 103-114.

GiA F.Y. \& Li Z.L. 1991: A study on the photoperiodic diapause of Dendrolimus spp. Forest Res. 4: 69-71 [in Chinese, English abstr.].

GILSON W.E. 1963: Differential respirometer of simplified and improved design. Science 141: 531-532.

Goto M., Sekine Y., Outa H., HujikuRa M. \& Suzuki K. 2001: Relationship between cold hardiness and diapause, and between glycerol and free amino acid contents in overwintering larvae of the oriental corn borer, Ostrinia furnacalis. $J$. Insect Physiol. 47: 157-165.

Guedes R.N., Smith R.H. \& Guedes N.M. 2003: Host suitability, respiration rate and the outcome of larval competition in strains of the cowpea weevil, Callosobruchus maculatus. Physiol. Entomol. 28: 298-305. 
Han R.D., Ge F., Yardim E.N. \& He Z. 2005: The effect of low temperatures on diapause and non-diapause larvae of the pine caterpillar, Dendrolimus tabulaeformis Tsai et Liu (Lepidoptera: Lasiocampidae). Japan. J. Appl. Entomol. Zool. 40: 429-435.

Hofmann A.A. 1995: Acclimation: increasing survival at a cost. TREE 10: 1-2.

Holmstrup M., Bayley M. \& Ramløv H. 2002: Supercool or dehydrate? An experimental analysis of overwintering strategies in small permeable Arctic invertebrates. Proc. Natl. Acad. Sci. 99: 5716-5720.

Hou T.Q. 1987: The Pine Caterpillars in China. Science Press, Beijing, $311 \mathrm{pp}$. [in Chinese].

Huang L.L., Xue F.S., Wang G.H., Han R.D. \& Ge F. 2005: Photoperiodic response of diapause induction in the pine caterpillar, Dendrolimus punctatus. Entomol. Exp. Appl. 117: 127-133.

KLOK C.J. \& CHOwN S.L. 1998: Interactions between desiccation resistance, host-plant contact and the thermal biology of a leaf-dwelling sub-antarctic caterpillar, Embryonopsis halticella (Lepidoptera: Yponomeutidae). J. Insect Physiol. 44: 615-628.

Klok C.J., Chown S.L. \& Gaston K.J. 2003: The geographic ranges structure of the holly leaf-miner. III. Cold hardiness physiology. Funct. Ecol. 17: 858-868.

Leather S.R., Walters K.F.A. \& Bale J. S. 1993. The Ecology of Insect Overwintering. Cambridge University Press, Cambridge, $255 \mathrm{pp}$.

LEE JR. R.E. 1989: Insect cold-hardiness: to freeze or not to freeze. BioScience 39: 308-313.

LEE JR. R.E. 1991: Principles of insect low temperature tolerance. In Lee Jr. R.E. \& Denlinger D.L. (eds): Insects at Low Temperature. Chapman and Hall, New York, 513 pp.

Lee JR. R.E. \& DenLinger D.L. 1991: Insects at Low Temperature. Chapman and Hall, New York, pp. 17-46.

Lee JR. R.E., Chen C.P. \& Denlinger D.L. 1987: A rapid coldhardening process in insects. Science 238: 1415-1417.

Lee JR. R.E., Damodaran K., Yi S.X. \& Lorigan G.A. 2006: Rapid coldhardening increases membrane fluidity and cold tolerance of insect cells. Cryobiology 52: 459-463.

LeinaAs H.P. \& FJellberg A. 1985: Habitat structure and life history strategies of two partly sympatric and closely related, lichen feeding collembolan species. Oikos 44: 448-458.

LeinaAs H.P. \& Sømme L. 1984: Adaptations in Xenylla maritima and Anurophorus laricis (Collembola) to lichen habitats on alpine rocks. Oikos 43: 197-206.

Li Z.L. \& Gia F.Y. 1989: Photoperiodic reaction of the pine caterpillar Dendrolimus tabulaeformis Tsai et Liu. Acta Entomol. Sin. 32: 410-417 [in Chinese, English abstr.].

LIU Q.S., Zhang P. \& FAN Z.Y. 2005: Analysis of carbohydrates by high performance anion exchange chromatography with pulsed amperometric detection (HPAE-PAD). Modern Sci. Instruments 1: 75-78 [in Chinese, English abstr.].

Pullin A.S. \& Bale J.S. 1989: Effects of low temperature on diapausing Aglais urticae and Inachis io (Lepidoptera: Nymphalidae): Cold hardiness and overwintering survival. $J$. Insect Physiol. 35: 277-281.

Rickards J., Kelleher M.J. \& Storey K.B. 1987: Strategies of freeze avoidance in larvae of the goldenrod gall moth, Epiblema scudderiana: Winter profiles of a natural population. $J$. Insect Physiol. 33: 443-450.

Ring R.A. 1982: Freezing-tolerant insects with low supercooling points. Comp. Biochem. Phys. (A) 73: 605-612.

Salt R.W. 1961: Principles of insect cold-hardiness. Annu. Rev. Entomol. 6: 55-74.

Sinclair B.J., Vernon P., KLoK C.J. \& Chown S.L. 2003a: Insects at low temperatures: an ecological perspective. Trends Ecol. Evol. 5: 257-262.

Sinclair B.J., Klok C.J., Scott M.B., Terblanche J.S. \& Chown S.L. 2003b: Diurnal variation in supercoling points of three species of Collembola from Cape Hallett, Antarctica. $J$. Insect Physiol. 49: 1049-1061.

Sømme L. \& Block W. 1982: Cold hardiness of Collembola at Signy Island, Maritime Antarctic. Oikos 38: 168-176.

Šlachta M., Vambera J., ZahradníčKovÁ H. \& KošŤÁL V. 2002: Entering diapause is a prerequisite for successful coldacclimation in adult Graphosoma lineatum (Heteroptera: Pentatomidae). J. Insect Physiol. 48: 1031-1039.

Spicer J.I. \& Gaston K.J. 1999: Physiological Diversity and its Ecological Implications. Blackwell, Oxford, $241 \mathrm{pp}$.

Storey K.B. \& Storey J.M. 1988: Freeze tolerance in animals. Physiol. Rev. 68: 27-84.

Tauber M.J., Tauber C.A. \& Masaki S. 1986: Seasonal Adaptations of Insects. Oxford University Press, New York, 411 pp.

WANG X.H. \& KANG L. 2005: Differences in egg thermotolerance between tropical and temperate populations of the migratory locust Locusta migratoria (Orthoptera: Acridiidae). J. Insect Physiol. 51: 1277-1285.

Worland M.R. \& BLOCK W. 1999: Ice-nucleating bacteria from the guts of two sub-Antarctic beetles, Hydromedion sparsutum and Perimylops antarcticus (Perimylopidae). Cryobiology 38: 60-67.

Worland M.R. \& Convey P. 2001: Rapid cold hardening in Antarctic microarthropods. Funct. Ecol. 15: 515-524.

Worland M.R., LeinaAs H.P. \& Chown S.L. 2006: Supercooling point frequency distributions in Collembola are affected by moulting. Funct. Ecol. 20: 323-329.

ZhaO Y.X. \& Kang L. 2000: Cold tolerance of the leafminer Liriomyza sativae (Dipt., Agromyzidae). J. Appl. Entomol. 124: $185-189$.

Received March 10, 2008; revised and accepted May 27, 2008 